\title{
Do you know this syndrome? Werner syndrome*
}

\section{Özlem Bilgiç ${ }^{1}$}

DOI: http:/ /dx.doi.org/10.1590/abd1806-4841.20174640

\section{CASE REPORT}

A 38-year-old man was admitted to our outpatient clinic for non-healing ulcers on the right Achilles tendon region, and left lateral and medial malleolar regions for 10 months (Figure 1). Treatments with various topical therapies and skin grafts had failed. Evaluation of organ system involvement and serologic testing for systemic sclerosis were negative. On physical examination, he presented short stature, low bodyweight, senile appearance, greying hair, bird-like face, thin extremities with atrophic and tight skin, flat feet, and highpitched voice (Figures 1 and 2). The patient was born

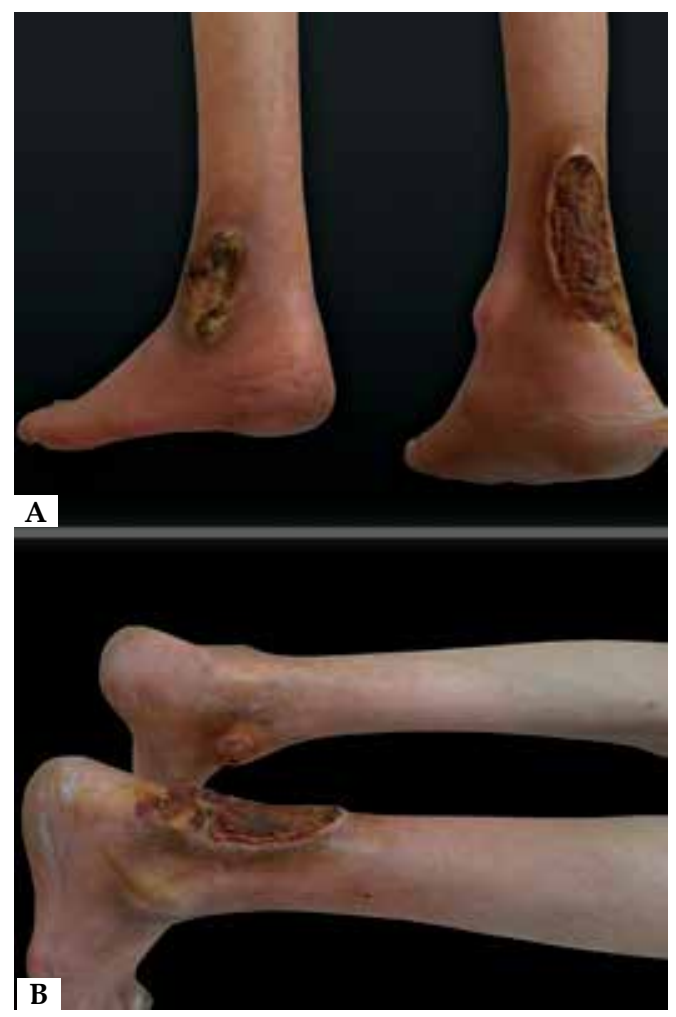

Figure 1: a) Intractable leg ulcers on the right Achilles tendon and left lateral and medial malleoli. (b) Thin extremities with atrophic and tight skin as scleroderma-like appearance from nonconsaguineous parents and was on oral antidiabetic medication and had cataract surgeries in both eyes. Although he has been married for 9 years, he had no children. Radiological examinations for leg ulcers revealed calcification in the Achilles tendon and an endocrinology consultation resulted in diagnoses of type 2 diabetes mellitus, primary hypogonadism and secondary osteoporosis.

\section{DISCUSSION}

Werner syndrome (WS) is a rare autosomal recessive premature aging disorder that starts after puberty. It has a 1:1,000,0001:10,000,000 overall incidence and is seen in approximately 1:100,000 Japanese individuals. ${ }^{1}$ WS is associated with mutations of the WRN gene, which participates in DNA replication and repair, telomere maintenance, and apoptosis, resulting in multisystem involvement. ${ }^{1,2}$

In general, the first clinical sign is a lack of the pubertal growth spurt in the teenage years; this leads to characteristic short statures and low body weights in WS patients. In the second and third decades of life, WS individuals manifest skin and hair anom-

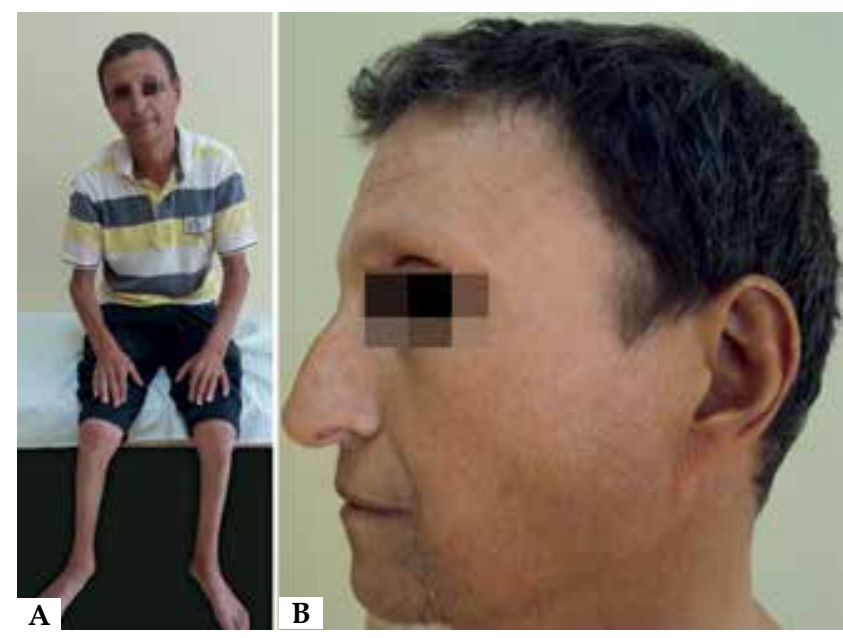

Figure 2: (a) Short stature, low bodyweight, thin extremities (b) bird-like face with beaked nose, senile appearance, thinning and graying of hair on scalp and beard area

Received on 16.04.2015

Approved by the Advisory Board and accepted for publication on 20.07.2015

* Study conducted at the School of Medicine, Selcuk University, Konya,Turkey. Financial support: none.

Conflict of interest: none.

1 School of Medicine, Selcuk University - Konya, Turkey.

@2017 by Anais Brasileiros de Dermatologia 
alies, voice changes (high-pitched, squeaky, hoarse) followed by bilateral cataracts, type 2 diabetes mellitus, dyslipidaemia, hypogonadism, osteoporosis, bone deformities (flat foot, hallux valgus) and atherosclerosis (coronary heart disease, cerebral hemorrhage/ infarction). Patients also experience an increased risk of cancers (thyroid neoplasms, malignant melanomas, soft tissue sarcomas) and nervous system disorders and usually die from cancer or arteriosclerosis by the fifth decade. ${ }^{1-6}$

Patients may refer to a dermatologist with many typical skin findings of WS, including hair loss, thinning and graying of hair, scleroderma-like skin changes, prematurely aged face, perioral radial scratching, skin wrinkling, nail dystrophies, clavus/callus, skin ulcers, intractable leg ulcers, soft tissue calcifications or skin cancers. ${ }^{1,5}$

The diagnosis of WS is performed based on the revised criteria listed in table $1 .{ }^{4}$ If all of the cardinal signs are present, or a gene mutation is detected in addition to at least three cardinal signs, the diagnosis of WS is confirmed. A WS diagnosis is suspected if two or more cardinal signs are present or if 1-2 cardinal signs are present in addition to other signs. Other premature aging syndromes, including Hutchinson-Gilford progeria syndrome and Rothmund Thomson syndrome, may be considered in a differential diagnosis of WS. However, symptoms of these syndromes emerge earlier than in WS. ${ }^{1}$

Currently, treatment options for WS are only symptomatic.
TABLE 1: Revised diagnostic criteria for Werner syndrome

I. Cardinal signs and symptoms (onset over 10 until 40 yearsof-age)

1. Progeroid changes of hair

2. Cataract

3. Changes of skin, Intractable skin ulcers

4. Soft-tissue calcification

5. Bird-like face

6. Abnormal voice

II. Other signs and symptoms

1. Abnormal glucose and/or lipid metabolism

2. Deformation and abnormality of the bone

3. Malignant tumors

4. Parental consanguinity

5. Premature atherosclerosis

6. Hypogonadism

7. Short stature and low bodyweight

III. Genetic testing

Confirmed: All cardinal signs or a gene mutation $+\geq 3$ cardinal signs

Suspected: $\geq 2$ cardinal signs or 1-2 cardinal signs + other signs

Source: Takemoto M, et al, $2013{ }^{4}$

The early diagnosis of WS is important in reducing complications and to prolong lifespan. Affected individuals should be examined regularly for secondary metabolic disorders, cardiac/cerebral atherosclerosis and associated cancers. $\square$

Abstract: Werner syndrome is a rare autosomal recessive disorder, caused by mutations in the WRN gene. Clinical findings include: senile appearance, short stature, grey hair, alopecia, bird-like face, scleroderma-like skin changes, skin ulcers, voice abnormalities, cataracts, osteoporosis, type 2 diabetes mellitus, ischemic heart disease and hypogonadism. The syndrome begins to become apparent in adolescence but it is usually diagnosed in the third or fourth decade of life. Since the patients usually die by the age of 40-50 years related to malignant neoplasms or atherosclerotic complications, they should be closely followed and treated for complications

Keywords: Leg ulcer; Progeria; Scleroderma, localized; Werner syndrome

\section{REFERENCES}

1. Coppedè $\mathrm{F}$. The epidemiology of premature aging and associated comorbidities Clin Interv Aging. 2013;8:1023-32.

2. Friedrich $K$, Lee L, Leistritz DF, Nürnberg G, Saha B, Hisama FM, et.al. WRN mutations in Werner syndrome patients: genomic rearrangements, unusual intronic mutations and ethnic-specific alterations. Hum Genet. 2010;128:103-11.

3. Duvic M, Lemak NA. Werner's syndrome. Dermatol Clin. 1995;13:163-8.

4. Takemoto M, Mori S, Kuzuya M, Yoshimoto S, Shimamoto A, Igarashi M, et al. Diagnostic criteria for Werner syndrome based on Japanese nationwide epidemiological survey. Geriatr Gerontol Int. 2013:13:475-81.

5. Bes C, Vardi S, Güven M, Soy M. Werner's syndrome: a quite rare disease for differential diagnosis of scleroderma. Rheumatol Int. 2010;30:695-8.

6. Lauper JM, Krause A, Vaughan TL, Monnat RJ Jr. Spectrum and risk of neoplasia in Werner syndrome: a systematic review. PLoS One. 2013;8:e59709.

\author{
MAILING ADDRESS: \\ Özlem Bilgiç \\ Selçuk Üniversitesi Tıp Fakültesi Hastanesi \\ Deri ve Zührevi Hastalkklar Anabilim Dalı \\ Alaeddin Keykubad Kampüsü \\ 42075 Selçuklu \\ Konya, Turkey. \\ Email:bilgicozlem@yahoo.com
}

How to cite this article: Bilgiç Ö. Do you know this syndrome? Werner syndrome. An Bras Dermatol. 2017; 92(1):271-2. 